\title{
New records of Gypsophila perfoliata (Caryophyllaceae) in Poland
}

Artur Pliszko

\begin{abstract}
New records of Gypsophila perfoliata (Caryophyllaceae) in Poland. - Acta Mus. Siles. Sci. Natur. 65:
\end{abstract} 215-218, 2016.

\begin{abstract}
The paper presents two new records of alien Gypsophila perfoliata in Poland. It was found on 16 September 2016 in Bodzanów and Łapczyca, Lesser Poland Voivodeship, southern Poland, growing on roadside slopes and in roadside ditch. The updated map of distribution is presented using the ATPOL cartogram method, and the pathways of introduction and spreading are discussed.
\end{abstract}

Key words: alien plant, ATPOL cartogram method, distribution, halophyte, Poland.

\section{Introduction}

Gypsophila perfoliata L. (G. trichotoma Wend.), a perennial herb of the family Caryophyllaceae, is native to Central and Southwestern Asia and Southeastern Europe. It occurs in Russia, China, Mongolia, Kazakhstan, Turkmenistan, Transcaucasia (Azerbaijan, Armenia, and Georgia), Romania, Ukraine (Crimea), Bulgaria, and Turkey (Dequan \& Turland 2001, Marhold 2011). It is found usually in forest grasslands, on steppe and coastal sands and rocks, wet riversides, on saline-alkaline soils (Dequan \& Turland 2001, Petrova 2015). According to Mucina (1997), G. perfoliata is a species characteristic of mediterranean and thermo-atlantic perennial salt-marsh scrub communities of the class Salicornietea fruticosae. It belongs to the ecological and physiological group of salt conservators or hyperhalophytes, which are adapted to the conditions of salinization by salt conservation (Glukhov et al. 2014). Gypsophila perfoliata was introduced to Central and Eastern Europe as well as to North America, where is naturalized in some countries (Marhold 2011, Randall 2012).

In Poland, G. perfoliata was reported for the first time from Ostrowiec Świętokrzyski in 1957 as a casual alien (Kuc 1958). Nowadays, it is known from a few localities and is treated as an established alien plant that occurs in anthropogenic habitats (Tokarska-Guzik et al. 2012, Bartoszek \& Stachurska-Swakoń 2014, 2015). For example, it has been recorded from railway areas in Zamość and Hrubieszów (Święs \& Wrzesień 2002), dump of steelwork in Kraków (Guzik 2003), industrial areas in Stalowa Wola (Krawczyk 2010) and roadside verge in Stróża near Myślenice (Bartoszek \& Stachurska-Swakoń 2014, 2015). This paper presents two new records of G. perfoliata in southern Poland.

\section{Material and methods}

Gypsophila perfoliata was identified based on morphological characters given by Dequan \& Turland (2001) and Rutkowski (2004). National distribution map was prepared using the ATPOL cartogram method (Zając 1978), where the basic unit is a square of $10 \mathrm{~km}$ side. Syntaxonomical data followed Matuszkiewicz (2008). Voucher specimens of G. perfoliata are deposited in the Herbarium of the Institute of Botany of the Jagiellonian University in Kraków (KRA). 


\section{Results and discussion}

Gypsophila perfoliata was discovered on 16 September 2016 in Bodzanów and Łapczyca, between Wieliczka and Bochnia, Lesser Poland Voivodeship, southern Poland. These two localities are situated within the units EF71 and EF72 of the ATPOL cartogram grid, and currently G. perfoliata is known from ten $10 \mathrm{~km}$ cartogram units in Poland (Fig. 1). In Bodzanów it grows on roadside slope (GPS coordinates: $49^{\circ} 58.965^{\prime} \mathrm{N} / 20^{\circ} 09.420^{\prime} \mathrm{E}, 237 \mathrm{~m}$ a.s.l.) and its population consists of 77 individuals (six mature and 71 young plants). In Łapczyca, however, it occurs on roadside slope (GPS coordinates: $49^{\circ} 57.741^{\prime} \mathrm{N} / 20^{\circ} 21.423^{\prime} \mathrm{E}$, $211 \mathrm{~m}$ a.s.1.) and in roadside ditch (GPS coordinates: $49^{\circ} 57.735^{\prime} \mathrm{N} / 20^{\circ} 21.495^{\prime} \mathrm{E}, 215 \mathrm{~m}$ a.s.1.), where its population consists of 114 individuals altogether (six mature and 105 young plants on roadside slope, and three mature plants in roadside ditch, respectively) (Fig. 2). In presented habitats the cover of plants is of initial character, and G. perfoliata occurs accompanied by vascular plant species typical of communities from the classes Stellarietea mediae (e.g. Atriplex patula L., Chaenorhinum minus (L.) Lange, Chenopodium glaucum L., Erigeron canadensis L., Galinsoga parviflora Cav., Lactuca serriola L., Polygonum aviculare L., Setaria pumila (Poir.) Roem. \& Schult., Sonchus oleraceus L.), Artemisietea vulgaris (e.g. Artemisia vulgaris L., Medicago lupulina L., Solidago canadensis L.), Epilobietea angustifolii (e.g. Calamagrostis epigejos (L.) Roth, Populus tremula L., Salix caprea L.), and Molinio-Arrhenatheretea (e.g. Achillea millefolium L., Leontodon autumnalis L., Plantago lanceolata L., Trifolium pratense L.).

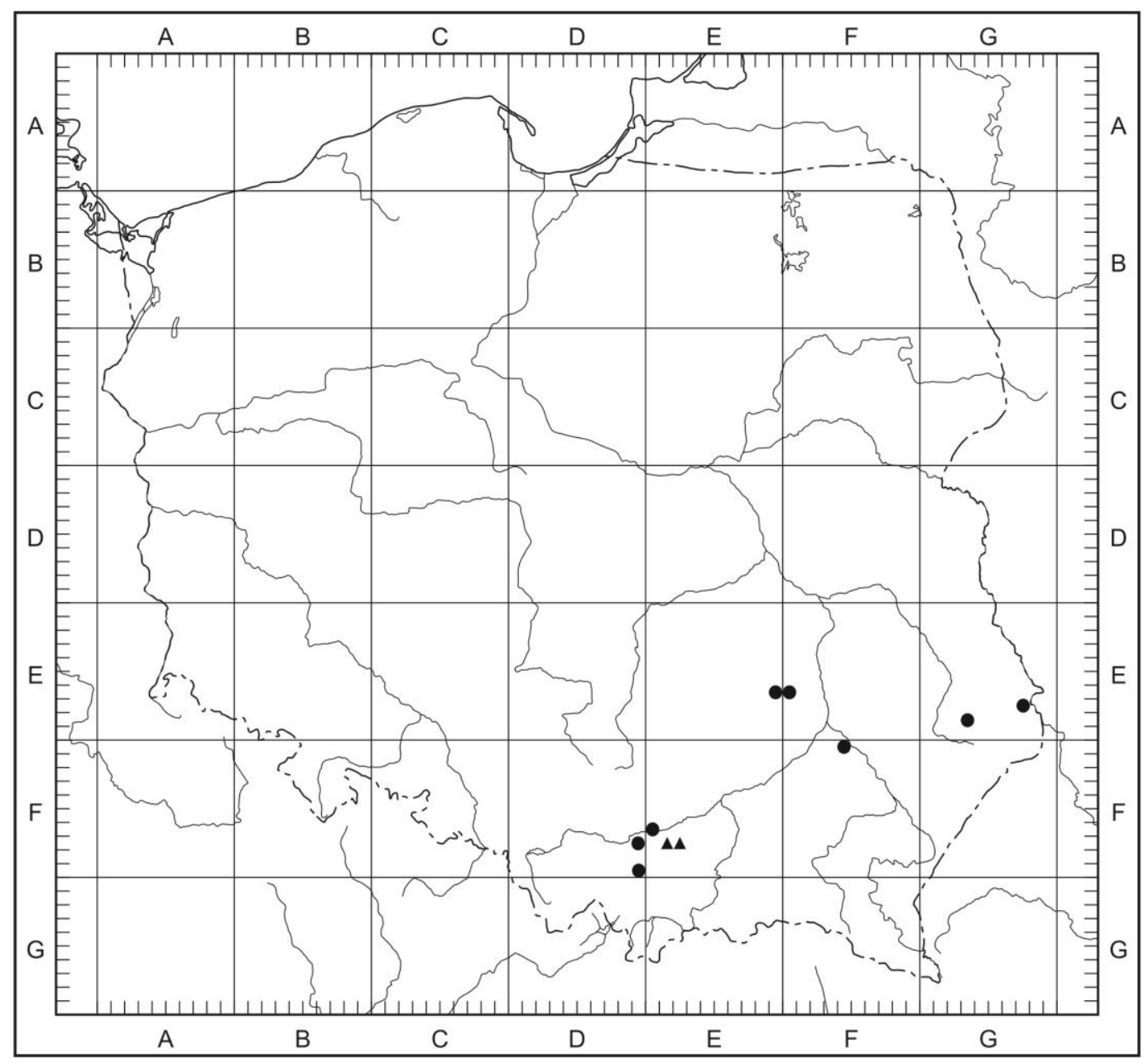

Fig 1: Distribution map of Gypsophila perfoliata in Poland ( - known localities; $\boldsymbol{\Delta}-$ new localities). 

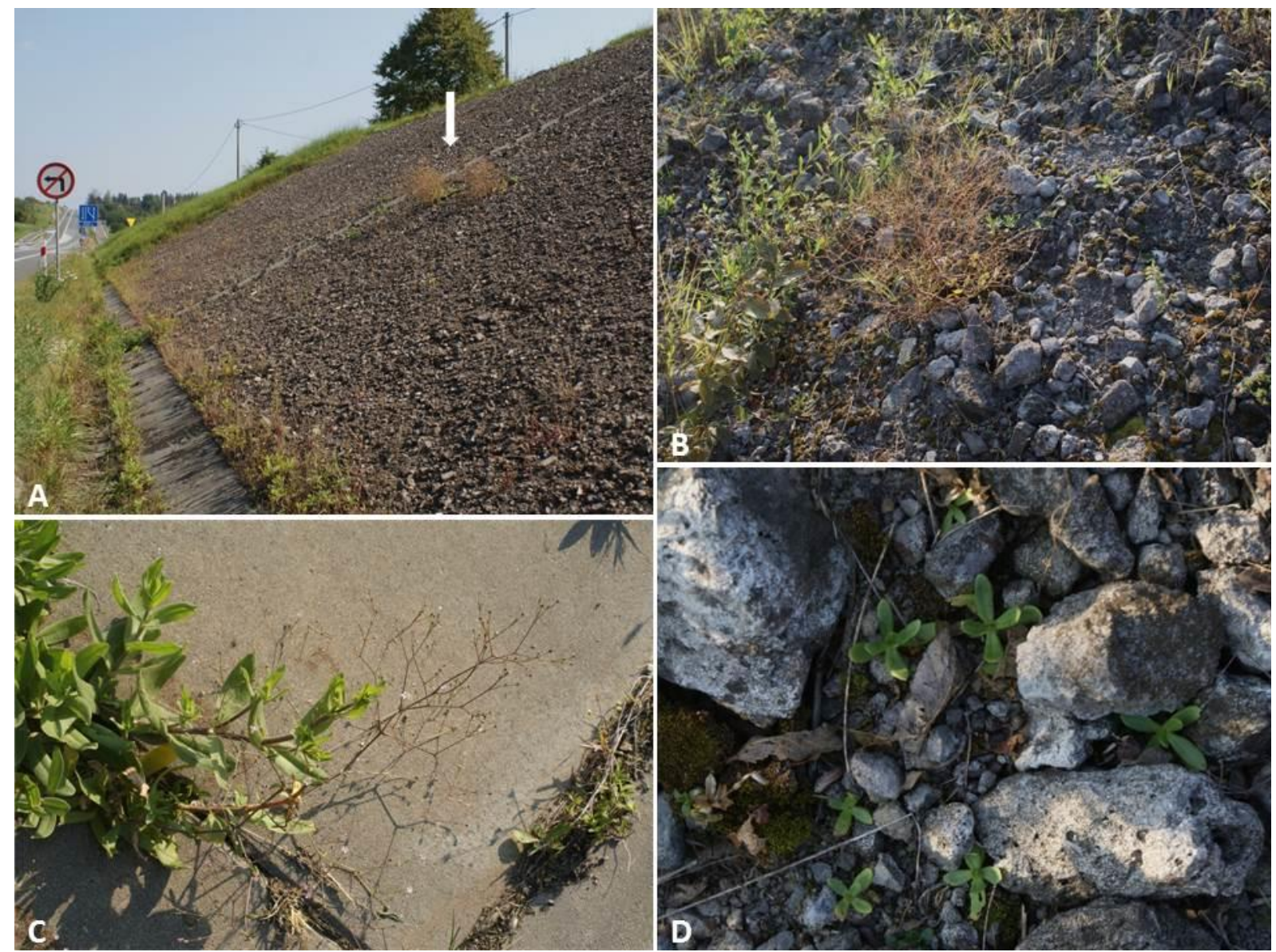

Fig 2: Photographic documentation of Gypsophila perfoliata from new localities in Poland: A - specimens on roadside slope in Bodzanów, B - fruiting specimen on roadside slope in Łapczyca, C - flowering specimen in roadside ditch in Łapczyca, D - young vegetative specimens on roadside slope in Łapczyca (made by A. Pliszko, 16 September 2016).

A low number of mature individuals of $G$. perfoliata recorded in Bodzanów and Łapczyca seems to be a consequence of early stage of colonization, however, a relatively large number of young vegetative individuals suggests that its sexual reproduction can be very successful in new areas. Glukhov et al. (2014) evidenced that the predominance of young specimens in $G$. perfoliata population in conditions of a slag dump is an expression of its adaptive strategy. The occurrence of G. perfoliata in Bodzanów and Lapczyca confirms the pattern that the road transport, similarly to railway transport (Jehlík \& Dostálek 2008), is a very important pathway of its introduction. Moreover, the species is spreading along the roadsides, especially after the extention and modernization of road tracks, when the newly created habitats (e.g. slopes, verges, ditches) are open and uncolonized by other plant species. A regular using of salt to melt snow and ice on roads in winter makes the roadside habitats more suitable for halophilic G. perfoliata. Bartoszek \& Stachurska-Swakoń (2014) suggested that $G$. perfoliata has an invasive potential, however, further observations on its impact and spreading are needed.

\section{References}

Bartoszek W. \& Stachurska-Swakoń A. (2014): Gypsophila perfoliata L. (Caryophyllaceae) - new, potentially invasive species in Poland. - Biodiv. Res. Conserv., Suppl. 1: 14.

- (2015): Gypsophila perfoliata L., pp. 98-100. In: Zając A. \& Zając M. (eds): Rozmieszczenie kenofitów w 
Karpatach Polskich i na ich przedpolu, Nakładem Instytutu Botaniki Uniwersytetu Jagiellońskiego, Kraków, $304 \mathrm{pp}$.

Dequan L. \& Turland N.J. (2001): Gypsophila Linnaeus., pp. 108-113. In: Wu C.Y., Raven P.H. \& Hong D.Y. (eds): Flora of China, vol. 6, Caryophyllaceae through Lardizabalaceae, Science Press \& Missouri Botanical Garden Press, Beijing \& St. Louis, 512 pp.

Glukhov O.Z., Kharkhota G.I., Prokhorova S.I. \& Agurova I.V. (2014): Adaptive strategies of the halophyte populations. - Ann. Bot. (Roma) 4: 115-124.

Guzik J. (2003): Hałda huty im. T. Sendzimira w Krakowie miejscem występowania interesujących obcych gatunków roślin. - Archiwum Ochrony Środowiska 29(2): 13-19.

Jehlík V. \& Dostálek J. (2008): Influence of railway transport in the South-East of Slovakia on formation of adventive flora in Central Europe. - Biodiv. Res. Conserv. 11-12: 27-32.

Krawczyk R. (2010): Notatki florystyczne z północnej części Kotliny Sandomierskiej (SE Polska). - Fragm. Flor. Geobot. Polonica 17(1): 9-18.

Kuc M. (1958): Gypsophila trichotoma Wend. w środkowej Polsce. - Fragm. Flor. Geobot. 3(2): 29-33.

Marhold K. (2011): Caryophyllaceae. In: Euro+Med Plantbase - the information resource for EuroMediterranean plant diversity. [available from http://ww2.bgbm.org/EuroPlusMed].

Matuszkiewicz W. (2008): Przewodnik do oznaczania zbiorowisk roślinnych Polski. Wydawnictwo Naukowe PWN, Warszawa, 537 pp.

Mucina L. (1997): Conspectus of classes of European vegetation. - Folia Geobot. Phytotax. 32: 117-172.

Petrova A. (2015): Gypsophila trichotoma Wend. In: Peev D. et al. (eds): Red data book of the Republic of Bulgaria, Digital edition, vol. 1, Plants and fungi, Bulgarian Academy of Sciences \& Ministry of Environment and Water, Sofia. [available from http://e-ecodb.bas.bg].

Randall R.P. (2012): A global compendium of weeds. $2^{\text {nd }}$ edition. Department of Agriculture and Food, Western Australia, 1124 pp.

Rutkowski L. (2004): Klucz do oznaczania roślin naczyniowych Polski niżowej. Wydawnictwo Naukowe PWN, Warszawa, 814 pp.

Święs F. \& Wrzesień M. (2002): Rare vascular plants of railway areas in Central-Eastern Poland. I. Lublin Upland, eastern part, Roztocze, Volhynia Upland. - Annales UMCS Sec. C 57: 1-23.

Tokarska-Guzik B., Dajdok Z., Zając M., Zając A., Urbisz A., Danielewicz W. \& Hołdyński C. (2012): Rośliny obcego pochodzenia w Polsce ze szczególnym uwzględnieniem gatunków inwazyjnych. Generalna Dyrekcja Ochrony Środowiska, Warszawa, 197 pp.

Zając A. (1978): Atlas of distribution of vascular plants in Poland (ATPOL). - Taxon 27(5-6): 481-484.

Author's address: Artur Pliszko, Department of Taxonomy, Phytogeography and Paleobotany, Institute of Botany, Jagiellonian University in Kraków, Kopernika 31, 31-501 Kraków, Poland.

E-mail: artur.pliszko@uj.edu.pl 